\title{
CIVIL LIABILITY OF ARBITRATORS
}

\author{
Agata Cevc, PhD, Senior judicial advisor \\ Supreme Court of the Republic of Slovenia \\ Tavčarjeva ulica 9, Ljubljana, Slovenia \\ agata.cevc@gmail.com
}

\begin{abstract}
The paper aims to determine situations when arbitrators are personally liable for damages caused and when they enjoy immunity because of their judicial role.

There is no uniform approach regarding civil liability of arbitrators. The question is closely connected with the dual nature of arbitration that has a judicial mission despite a contractual origin. Arbitrator's power derives from a private contract and they receive payment from the parties in exchange for professional services. However, they act as private judges - they resolve disputes which require a binding decision of an impartial third party. Due to the double role of arbitrators, this paper will separately discuss civil liability for breaches of arbitrator's contractual obligations and breaches of duties regarding their judicial role.

Common law countries provide immunity to arbitrators based on equating their function to that of judges. On the other hand, civil law countries emphasize the contractual relationship between the arbitrators and parties and determine liability according to ordinary law of contract. Despite different starting points most jurisdictions accord a certain degree of immunity to arbitrators in the exercise of their judicial role to ensure the finality of arbitral awards and protect the independence and impartiality of arbitrators. Arbitrators are therefore not liable for the procedural or material accuracy of their decisions because in such cases the parties can bring an action against an award. However, almost all legal systems exclude immunity in cases where the arbitrator intentionally violated his judicial duties. The differences between civil and common law countries are greater regarding liability for breaches of the arbitrator's contractual duties. Contractual limitations and exclusions of liability are also mentioned. The article concludes that absolute exclusions of liability are unenforceable in most jurisdictions.

The article will determine which law should apply to the issue of civil liability of international arbitral tribunals. In the absence of legislation and jurisprudence in Slovenia the paper suggests that qualified immunity should apply. Arbitrators should enjoy immunity for judicial acts, except in exceptional cases of fraud and deliberate violations of their judicial duties. For breaches of their contractual duties, arbitrators should be liable according to general rules of contract law.
\end{abstract}

Keywords: arbitration, civil liability of arbitrators 


\section{INTRODUCTION}

What are the consequences if the arbitrator does not fulfil his obligations? To what extent can he be liable for his errors or misconduct? International conventions and the UNCITRAL Model Law on International Arbitration are silent on the matter as the latter viewed this issue too controversial to provide a satisfactory uniform approach. ${ }^{1}$ Approaches adopted by national arbitration laws differ. Most common law countries (USA, England, Australia) expressly grant immunity, some civil law countries expressly provide liability (Italy, Austria, Spain) while most do not deal with the subject. ${ }^{2}$ Why do the approaches differ?

\section{DUAL ROLE OF ARBITRATORS}

The question of liability relates to the dual nature of arbitration that is contractual by origin but judicial by purpose and procedure. ${ }^{3}$ Arbitrators are contractually engaged to perform a service in exchange for renumeration. Unlike judges they are chosen and paid for by the parties directly and may negotiate their terms or refuse to be appointed. Since they are employed by the parties, they are not subject to the same disciplinary control. Although their power stems from individual arbitration agreements, their final decisions have a binding, res judicata effect. As the state ensures the enforcement of the awards it requires that the arbitration proceedings meet certain minimum standards. Arbitrators act as "private judges" and they assume similar responsibilities - they are obliged to independence. ${ }^{4} \mathrm{Be}$ cause the nature of the arbitrator's status is of a mixed status (both contractual and

1 Fouchard, P.; Gaillard E.; Goldman B., Fouchard, Gaillard, Goldman on international commercial arbitration Kluwer Law International, The Hague, 1999, pp. 592; Franck, S., The Liability of International Arbitrators: A Comparative Analysis and Proposal for Qualified Immunity, New York Law School Journal of International \& Comparative Law, Vol. 20, Issue 1, 2000, pp. 3; Holtzmann H; Neuhaus, J., $A$ Guide to the UNCITRAL Model Law on International Commercial Arbitration: Legislative History and Commentary, Kluwer Law International, The Netherlands, 2015, pp. 1119, 1148; Born, G., International Commercial Arbitration (Second Edition), Kluwer Law International, 2014, pp. 2027

2 For more detail see chapter 3.1. (regarding common law countries) and chapter 3.2 (regarding civil law countries)

3 Fouchard et. al, op. cit. note 1, p. 607

4 Smahi, N., The Arbitrator's Liability and Immunity Under Swiss Law - Part I, ASA Bulletin, Kluwer Law International, Vol. 34 Issue 4, 2016, pp 880-882; Pörnbacher, K.; Knief I., Liability of Arbitrators - Judicial Immunity versus Contractual Liability: Party Autonomy versus Autonomy of Arbitrators, Czech and Central European Yearbook of Arbitration, Juris, Huntington, 2012, pp. 212, 223; Mullerat R.; Blanch J., The Liability of Arbitrators: A Survey of Current Practice, Dispute Resolution International, Vol. 1., Issue 1, International Bar Association, 2007, pp. 100, 101; Lew, J.; Mistelis, L.; Kroll, S., Comparative International Commercial arbitration, Kluwer Law International, The Hague, 2003, pp. 255, 276, Hausmaninger, C., Civil Liability of Arbitrators - Comparative Analysis and Proposals for Reform, Journal of International Arbitration, Vol. 4, Issue 4, 1990, pp. 16 
jurisdictional) civil liability of arbitrators in their judicial role and their role as a contractual party will be analysed separately.

\section{ARBITRATORS AS JUDGES}

\subsection{Common law countries}

Common law countries accord a broad immunity to arbitrators comparable to that of judges. As they consider them to be "functional equivalent" of judges the U.S. courts have extended the absolute judicial immunity to arbitrators. ${ }^{5}$ Already in 1880 the Court held that arbitrators could not be sued for damages resulting from fraudulent or corrupt conduct. ${ }^{6}$ The arbitrator enjoyed immunity even when he conspired with the other party's attorneys to persuade the other arbitrators in rendering an unjust award. The Court held that "there is as much reason in his case for protecting and insuring his impartiality, independence, and freedom from undue influences, as in the case of a judge". ${ }^{7}$ In the past, U.S. courts provided a broad immunity to arbitrators extending to bad faith, non-disclosure of conflicts of interest, intentional misconduct, and similar malfeasance. ${ }^{8}$ Relying on case law, the Revised Uniform Arbitration Act 2000 expressly grants immunity to arbitrators to the same extent as judges. They enjoy immunity even if they fail to disclose a conflict of interest. ${ }^{9}$ Some states have also codified common law immunity for arbitrators (i.e. California, Florida, Wisconsin, Karolina, Utah). ${ }^{10}$

English jurisprudence adopted a similar approach and provided arbitrators with broad immunities. ${ }^{11}$ The English Arbitration Act 1996 confirmed this position

5 Le club de jurists: Ad hoc commitee, Report: The arbitrator's liability, Paris, 2017, pp. 100, 101; Brown, J., The Expansion of Arbitral Immunity Is Absolute Immunity a Foregone Conclusion, Journal of Dispute Resolution, Vol. 2009, Issue 1, 2009, pp. 229, 230

6 Jones v. Brown (1880); Hausmaninger, op. cit. note 4, p .15; Warwas, B., The Liability of Arbitral Institutions: Legitimacy Challenges and Functional Responses, T.M.C. Asser press, The Netherlands, 2017, pp. 255

7 Hoosac Tunnel Dock \& Elevator Co v. O'Brien (1884); Born, op. cit., note 1, p. 2031: Lew, et al, op. cit. note 4, p. 294

8 Franck, op. cit. note 1, p. 13, 14; Hausmaninger, op. cit. note 4, p. 29; Born, G., International Arbitration: Law and Practice (Second Edition), Kluwer Law International, 2016, pp. 144; Hwang M., Chung K., Cheng F., Claims Against Arbitrators for Breach of Ethical Dutie in Contemporary Issues in International Arbitration and Mediation, The Fordham Papers, New York, 2007, pp. 239

9 Uniform Arbitration Act, 2000 Section 14(a,c)

10 Warwas, op. cit. note 6, p. 270; Truli E., Lability v. quasi-judicial immunity of the arbitrator: the case against absolute arbitral immunity, The american review of international arbitration, Vol. 7, 2006, pp. 9; Clay, T., L'arbitre, Dalloz, Paris, 2001, pp. 455-457, fn. 7

11 Sutcliffe v. Thackrah, (1974) A.C.; 727; Arenson v. Arenson, (1977), A.C. 405; Fouchard et. al, op. cit. note 1, p. 593; Smahi, N., op. cit. note 4, p. 893, 894 
but allowed certain exceptions to immunity. Similar provisions are found in Australia and Kenya where "an arbitrator is not liable for anything done or omitted to be done in good faith in his or her capacity as arbitrator," 12 whereas in New Zealand arbitrators are not liable for negligence for acts and omissions in their capacity as arbitrators. ${ }^{13}$

\subsection{Civil law countries}

Civil law countries on the other hand focus on the contractual relationship between the arbitrator and the parties. This could in principle lead to liability according to ordinary law of contract. ${ }^{14}$ Some countries have included express provisions on liability. The Spanish law states that arbitrators can be liable for damages caused by bad faith, fraud or recklessness. ${ }^{15} \mathrm{~A}$ similar provision can be found in the Austrian arbitration law. Section 594/4 Zivilprozessordnung, provides that: "an arbitrator who does not or who does not timely fulfil his obligations ... shall be liable to the parties for all damage caused by his culpable refusal or delay". This is a mandatory provision which the parties cannot derogate by agreement. ${ }^{16}$ Pursuant to article 813-ter of the Italian Code of civil procedure, arbitrators may be held liable for damages for: 1 . fraudulent or grossly negligent omission or delay in the procedure (if he was removed) or in issuing the award or for 2. resignation without a proper cause. Romanian law also contains a provision regarding liability. ${ }^{17}$

Express provisions providing for liability are also found in Latin America (Peru, Argentina, Uruguay, Honduras etc.) and certain Arab countries (Lebanon, Tunisia, Indonesia, Saudi Arabia, UAE, etc.). ${ }^{18}$

12 Article 28. Australian International Arbitration Act 1974; article 39 Commercial Arbitration Act 2017; 16b(1) Kenyan Arbitration Act No. 11 2009; article 13 New Zealand Arbitration Act 1996; Born, op. cit, note 1, p. 2032; Clay, op. cit. note 10, p. 456; Redfern, A.; Hunter, M.; Blackaby N., Partasides C., Redfern and Hunter on International Arbitration, Sixth edition, Oxford University Press, New York, 2014, pp. 323, 324; Viscasillas P., Civil Liability of Arbitrators and Arbitral Institutions in International Commercial Arbitration: The Development of the Arbitration Laws and Rules in the Last 30 Years, World Arbitration And Mediation Review, Vol7, Issue 2, 2013, pp. 411, 417

13 Article 25 Singapore Arbitration Act

14 Smahi, op. cit. note 4, p. 882-885; Pörnbacher et. al., op. cit. note 4, p. 215; Hausmaninger, op. cit. note 4, p. 19

15 Ley de Arbitraje, 2003, article 21.1

16 Schwarz, F.; Konrad C., The New Vienna Rules, Arbitration International, Vol 23, Issue 4, 2007, pp. 619

17 Article 565 of the Romanian Code of civil procedure (Codul de procedură civilă)

18 Franck, op. cit. note 1, p. 40-44; Smahi, op. cit. note 4, p. 895; Le club de juristes, op. cit. note 5, p. 117-121; Truli, op. cit. note 10, p. 398; Viscasillas, op. cit. note 12, p. 418; Ramadurai R., Arbitration in Dubai; Immunity of Arbitration Tribunals, Recent Judicial Verdicts, International Conference on Challenges in Domestic and International Arbitration, Chennai, 2016, pp. 32 
The differences that appear considerable at first sight, are in practice not so great. Despite different starting point most legal systems reach similar conclusions regarding arbitrator's liability for judicial acts. ${ }^{19}$ Common law countries have restricted the application of judicial immunity, whereas civil law countries limited the broad contractual liability through statutory interpretation based on the similarities of their function to that of a judge.

\subsection{Immunity of arbitrators}

To prevent losing parties from harassing arbitrators, no legal system allows liability for any error of judgment arbitrators may commit. ${ }^{20}$

In the Netherlands for example the Court held that arbitrators are comparable to judges and should be able to judge freely. They are therefore only liable "in the event of intent, wilful misconduct or if they manifestly failed to exercise due care and skill. Thus the arbitrator who incorrectly concluded that the arbitration agreement was valid did not face liability." ${ }^{21}$ The Austrian courts have also restricted the contractual liability by applying the doctrine of judicial immunity by analogy to arbitrators. ${ }^{22}$ They set out two preconditions for the arbitrator to be held liable (in cases that do not fall within the scope of 594(4) Zivilprozessordnung): 1. the successful challenge of the award and 2. gross negligence on the part of the arbitrator. This means that they could not be liable for errors that are not reasons for which the award can be set aside. This approach has been criticised as too narrow since it could lead to the protection of arbitrators that had acted with criminal intent if the injured party missed the short time period for challenging the award. ${ }^{23}$ The Italian law also limits liability claims - they can be filed only after the arbitral award was successfully challenged and only for the reasons for which it was set aside. Outside the expressly envisaged cases arbitrators could therefore only liable when the state could be liable for judicial errors according to Law No. 117 of 13 April 1988 (i.e. not for the wrong interpretation of law or the wrong assessment

\footnotetext{
19 Hausmaninger, op. cit. note 4, p. 23

$20 \quad$ Fouchard et. al, op. cit. note 1, p. 593

21 ASB Greenwold v. NAI and arbitrators; Maisner M., Liability and Independence of the arbitrator, Czech and Central European Yearbook of Arbitration, Juris, Huntington, 2012 pp. 163, 164

22 OGH 9 Ob 126/04a (6.6. 2005); 5 Ob 30/16x (22. 3. 2016); Redfern et. al. op. cit. note 12, p. 322; Schwarz, et. al. op. cit. note 16, p. 619, 620; Maisner, op. cit. 21, pp. 163, 164; Grill, A; Lukic S., Arbitrators' Liability: Austrian Supreme Court Reconfirms Strict Standards, Kluwer Arbitration Blog, 2016 [http://arbitrationblog.kluwerarbitration.com/2016/09/01/arbitrators-liability-austrian-supreme-court-reconfirms-strict-standards/] Accessed 27.02.2019

23 Jens, G., Die Haftung des Schiedsrichters in der internationalen Handelsschiedsgerichtsbarkeit, Mohr Siebeck, Tübingen, 2009, pp. 434
} 
of facts and evidence) and after the successful challenge of the award. ${ }^{24} \mathrm{~A}$ comparable approach is found in Germany. It is assumed that the parties have implicitly agreed to a contractual limitation of liability - i.e. to grant arbitrators the same privilege of immunity as German judges (for acts in connection with deciding the dispute). This assumption can only be excluded explicitly. They would therefore be liable only when their acts qualify as a criminal offense. Since liability for intent cannot be excluded in advance, some argue, that arbitrators could be liable for intentional breaches. If the breach is not related to deciding the dispute or is only ancillary to the decision-making (for unjustified resignation, breach of duty of disclosure, breach of duty to deliver a formally correct award, breach of duty to issue an award in time, etc.), arbitrators can be liable according to general principles of contract. ${ }^{25}$ Some warn that this approach is not appropriate as it allows parties to agree to an unlimited standard of liability even though a certain degree of immunity is necessary to protect the judicial function (and not the arbitrator as a person). ${ }^{26}$ It is worth noting that the German judges' privilege (in terms of state liability for breaches of EU law) is not compatible with EU law (Köbler and Traghetti judgments). The same is true for the Italian approach. ${ }^{27}$ The liability of arbitrators in the UAE is also limited to cases of fundamental errors and intent. ${ }^{28}$ In Switzerland the doctrine is unanimous that liability should be limited to cases of intent or gross negligence. Controversy remains only regarding the ground for this limitation. ${ }^{29}$

Arbitrators generally enjoy a certain immunity that protects them from liability claims based on accusation that they reached the wrong decision (i.e. for falsely applying the law, for the assessment of facts and evidence or for procedural errors).

24 813-ter Codice di procedura civile; Dittrich, L.; Curatola M., Luca F., Commercial Arbitration: Italy, 2017

[https:/globalarbitrationreview.com/jurisdiction/1002557/italy] Accessed 07.03.2019

25 Franck, op. cit. note 1, p. 39; Pörnbacher, et al, op. cit. note 4, p. 217-219, 226; Hausmaninger, C., op. cit. note 4, p. 36, 37; Jens, G., op. cit. note 23, p. 430-432; K. Böckstiegel; S. M. Kröll; P. Nacimiento, Arbitration in Germany: the model law in practice, Second Edition, Wolters Kluwer Law \& Business, Alphen aan den Rijn, 2014, pp. 31, 152, 153, 750, 751, 783, 784

26 Jens, G., op. cit. note 23, p. 431

27 Terhechte, J. P., Judicial Accountability and Public Liability-The German "Judges Privilege" Under the Influence of European and International Law, German Law Journal, Vol. 13, No. 3, 2012, pp. 321-324, 328, 329; Case C-224/01 Köbler v Austria (2003) par. 51, 53, 55, 56, 59; Case C-173/03 Traghetti del Mediterraneo SpA v Repubblica italiana (2006) par. 46

28 Lagarde M., Liability of Arbitrators in Dubai: Still a Safe Seat of Arbitration, ASA Bulletin, Kluwer Law International 2015, Vol. 33 Issue 4, pp. 787, 804, 806

29 Smahi, op. cit. note 4, p. 876; Le club de juristes, op. cit. note 5, p. 132-135; Smahi, N., The Arbitrator's Liability and Immunity Under Swiss Law - Part II, ASA Bulletin, Kluwer Law International, Vol. 35 Issue 1, 2017, pp. 68-73 
This is necessary to ensure their independence and impartiality and guarantees the finality of the award. Parties should generally not be allowed to have the merits of the award reviewed through liability claims since this could lead to contrary decisions on the matter (even if it does not influence the res judicata effect of the award). ${ }^{30}$

\subsection{Limitations to immunity}

However, no legal system accords absolute immunity to arbitrators. In general arbitrators could not avoid liability for intentional breaches of their fundamental judicial duties. ${ }^{31}$

Even in the United States, more recent decisions show that the scope of arbitrator's immunity may be subject to exceptions with some courts denying immunity for failing to issue an award in a timely manner, for failing to act or for fraud or similar misconduct. ${ }^{32}$ The English Arbitration Act 1996 provides two situations where arbitrators can be liable: in case of unreasonable resignation and bad faith. ${ }^{33}$ The latter means: "(a) malice in the sense of personal spite or a desire to injure for improper reasons; or (b) knowledge of absence of power to make the decision in question." ${ }^{44}$ It also covers situations where an arbitrator accepted an appointment despite knowing he does not have the necessary qualifications or that he cannot exercise his function in a timely manner due to other commitments. ${ }^{35}$

In France there are no provisions regarding liability which could lead to the use of ordinary contract law. The courts have limited this liability and held that arbitrators benefit from judicial immunity - they can only be liable for personal fault that amounts to fraud, gross negligence or denial of justice. ${ }^{36}$ Claims based on general criticism that the arbitrator reached a wrong decision and for alleged breaches of procedural rules have been dismissed. ${ }^{37}$ There have however been a few successful claims before the French courts (once for untimely resignation, twice for lack of independence and twice for exceeding the deadline without asking for

\footnotetext{
$30 \quad$ Smahi, op. cit. note 29, pp 76

31 Fouchard et. al, op. cit. note 1, p. 593

32 Born, op. cit, note 1, p. 2032; Born, op. cit. note 8, p. 144

33 Article 25, 26, 29 English Arbitration Act 1996

34 Le club de juristes, op. cit. note 5, p. 111; Sutton D.; Gill J., Gearing, M., Russell on arbitration, Sweet \& Maxwell, London, 2007, p. 175

35 Lew, et al, op. cit. note 4, p. 294.

36 Le club de juristes, op. cit. note 5, p. 21.-31

37 Fouchard et. al, op. cit. note 1, p. 591-593, 598; Pörnbacher et. al., op. cit. note 4, p. 217
} 
an extension)..$^{38}$ In Annahold, the company discovered that the sole arbitrator was a financial consultant to the chairman of the other party and rendered his award despite Annahold requesting his resignation. The award was set aside on the grounds of invalid consent to the arbitration agreement (due to fraud). The court ordered the arbitrator to pay compensation, equal to the amount of fees received with interest from the date of the payment. ${ }^{39}$

The Raoul Duval case is comparable. The chairman of the arbitral tribunal began working for one of the parties on the day after the award had been rendered without disclosing this to the parties. The award was set aside, and Raoul Duval sought to receive compensation. The court found the arbitrator liable on a contractual basis and determined the compensation according to general rules of contract law in the amount of the arbitrator's (and the institution's) fees and additional costs incurred - the costs of the defence. ${ }^{40}$

Finland has a similar approach. The Supreme court has found the chairman of the arbitral tribunal liable for breach of his contractual duty of disclosure but stressed that the arbitrators are liable only in exceptional circumstances to preserve their independence and impartiality. ${ }^{41}$

Arbitrators can therefore be liable in tort or in contract. Damages are determined according to general rules and will generally cover the costs of the arbitration procedure - the fees paid to the arbitrator and institution, the costs incurred in their defence (lawyers' fees and travel expenses) and the costs of the procedure to set aside the award. The plaintiff cannot claim compensation in the amount of the value of the dispute as it does not reflect the damages incurred. ${ }^{42}$

Authors that try to determine situations where arbitrators are not protected by immunity within their judicial role generally agree that they should be liable for intentional fault or fraud. Since they breach their judicial obligation to act fairly and treat the parties equally, they do not deserve protection. ${ }^{43}$

\footnotetext{
38 Le club de juristes, op. cit. note 5, p. 17

39 Fouchard et. al, op. cit. note 1, p. 594, 595

40 Fouchard et. al, op. cit. note 1, p. 1092; Lew, et al, op. cit. note 4, p. 295.2

${ }_{41}$ Urho, Sirkka in Juuka Ruola 31. 1. 2005; Maisner, op. cit. 21, p. 157-160

42 Fouchard et. al, op. cit. 596; Lagarde, op. cit. note 28 p. 3; Alessi, D. Enforcing Arbitrator's Obligations: Rethinking International Commercial Arbitrators' Liability, Journal of International Arbitration, Vol.31, Issue 6, 2014, pp. 780; Giraud, P., Le devoir de l'arbitre de se conformer à sa mission, Bruylant, Bruxelles, 2017, pp. 121

43 Fouchard et. al, op. cit. note 1, p. 598, 599
} 


\section{ARBITRATORS AS CONTRACTUAL PARTIES}

In their judicial capacity arbitrators enjoy immunity which protects them from lawsuits for errors made in reaching their award - for the procedural or material accuracy of their decision. Liability claims must not enable the parties to challenge the content of the award since the parties have other legal remedies. In general, they could only be liable for breaches of their fundamental judicial duties. In some countries they could also be liable for clear, inexcusable negligence (i.e. if he does not give reasons and the award is declared invalid). However, since arbitrators assume their adjudicatory function on a contractual basis (they agree to perform a service in exchange for a fee), a fault committed in conducting the arbitral proceedings constitutes a breach of contract. As paid service providers the arbitrators are liable for serious breaches under ordinary contract law. ${ }^{44}$

Arbitrators have several contractual duties, that (broadly speaking) fall into four categories. Firstly, arbitrators must conduct the proceedings fairly, independently and impartially (duty of disclosure), treat the parties equally and respect their right to be heard. Secondly, arbitrators must complete their functions within the legal or contractual deadlines. Arbitrators must perform their obligations diligently and in a timely manner. If they fail to request for an extension of a deadline, they may face liability in some countries. Thirdly arbitrators must pursue their function until the award is made and cannot resign without valid grounds. Lastly arbitrators have a duty of confidentiality. ${ }^{45}$

The differences between civil law and common law countries regarding breaches not related to deciding the dispute are greater. The latter offer broader protection to arbitrators as they expressly provide immunity to arbitrators that extends to non-judicial acts (i. e. breaches of their administrative duties, such as breach of confidentiality). ${ }^{46}$ Immunity in the USA extends to all acts within the arbitral process unless the arbitrator loses his resemblance to a judge (for failing to act and due to fraud). ${ }^{47}$ Similarly in England administrative acts are also protected by immunity (with exception of bad faith and resignation). ${ }^{48}$

Civil law countries adopt a stricter approach. Liability regarding breaches not related to deciding the dispute is determined according to general rules of con-

\footnotetext{
44 Fouchard et. al, op. cit. note 1, p. 619; Böckstiegel et al. op. cit. note 25, p., 30, 31, 153, 783

45 Fouchard et. al, op. cit. note 1, p. 609-612

46 Jens, op. cit. note 23, p. 431.433

47 Le club de juristes, op. cit. note 5, p. 99-103; Born, op. cit. note 8, p. 144; Jens, op. cit. note 23, p. 431.43

48 Jens, op. cit. note 23, p. 431.433.
} 
tract law so that arbitrators may also be liable for simple negligence. To identify situations where arbitrators can incur liability it is helpful to distinguish between best efforts obligations and obligations to achieve a result. Arbitrators that resign without a valid reason or fail to extend the deadline for rendering an award breach the obligation of result. This suffices for their liability. In France for example an arbitrator was liable for rendering the award after the time limit without asking for an extension. ${ }^{49}$ Regarding other duties arbitrators are only required to fulfil them with due diligence and (professional) care and they are not obliged to achieve a particular result) since the outcome of the dispute is uncertain. Different authors offer different classifications of these duties. ${ }^{50}$ However, they must not breach their fundamental duties. ${ }^{51}$ The Spanish Supreme court found two arbitrators liable for committing a serious and inexcusable error when they excluded the co-arbitrator (appointed by the plaintiff) from deliberating and voting on the award thus violating the principle of collegiality and due process. As the award was set aside (for violating public policy) the court ordered them to pay damages in the amount of arbitration fees received (with interest). ${ }^{52}$

In all legal systems arbitrators could incur liability for non-performance (for failing to render an award at all or in a timely manner). In civil law countries they could be liable not only for unjustified resignation and not fulfilling their obligations (at all or in a timely manner) but also for negligence since arbitrators (who are paid professionals) are obliged to perform their contractual duties with due care and skill. They could face liability for breaches of confidentiality or failing to conduct the proceedings according to the party's agreement (for example for issuing the award in the wrong place if it cannot be enforced in the country of the losing party)..$^{53}$

In the absence of a choice of law clause by the parties, which law should apply to the arbitrator's contract? The doctrine agrees that the applicable law should be determined by the law of the seat of the arbitral tribunal or institution instead of the law applicable to the party that performs the characteristic performance $-i$. e. the habitual residence of the arbitrator. ${ }^{54}$ The latter criterion would lead to the application of different standards of liability for members of the same panel. On the

\footnotetext{
49 Le club de juristes, op. cit. note 5, p. 27, 28

50 Smahi, op. cit. note 4, p. 884-888; Alessi, op. cit. note 42, p. 664-778; Giraud, op. cit., note 42 p. 120

51 Fouchard et. al, op. cit. note 1, p. 621

52 Le club de juristes, op. cit. note 5, p. 116

53 Sammartano M. R., International arbitration law and practice, JurisNet, Huntington, 2014, p. 521

54 Article 4(2) of the EC Regulation No 593/2008 on the law applicable to contractual obligations (Rome I); article 20 Zakon o mednarodnem zasebnem pravu in postopku, Ur.l. RS, št. 56/1999
} 
other hand, the law of the seat provides equal treatment for all, is easily identified and generally has the closest connection (as it will often govern the proceedings on a subsidiary basis and is usually the place of the performance of the contract). ${ }^{55}$

\section{CONTRACTUAL EXCLUSIONS (LIMITATIONS) OF LIABILITY}

Even though cases of arbitrators (and institutions) being convicted to pay damages are rare, most institutional arbitration rules provide exclusion clauses. ${ }^{56} \mathrm{By}$ appointing an arbitrator according to these rules, the exclusion clause is automatically incorporated in the arbitrator's contract. ${ }^{57}$ Most arbitration rules exclude both their own liability and the arbitrator's liability for acts and omissions in connection with the arbitration with an exception in cases where the arbitrator or institution acted intentionally.

LCIA (2014) states that arbitrators are not liable for "any act or omission in connection with any arbitration," except for the consequences of "conscious and deliberate wrongdoing." ${ }^{58}$ The rules of WIPO (2014) ${ }^{59}$ in HKIAC $(2018)^{60}$ are comparable. They provide liability only in cases of "deliberate" or "dishonest" wrongdoing. ${ }^{61}$ German Institution of Arbitration (DIS) (1998) exonerates the arbitrators from liability "in connection with arbitral proceedings" save for "intentional or grossly negligent breach of duty." ${ }^{62}$ Similar provisions are found in the arbitration rules of SCC ${ }^{63}$ and Swiss chamber's arbitration institution. ${ }^{64}$ Some institutions go further and accord absolute immunity to judges (NAI (2015), ${ }^{65}$

55 Fouchard et. al, op. cit. note 1, p. 558; Franck, op. cit. note 1, p. 49-53; Lew, et al, op. cit. note 4, p. 278; Hausmaninger, op. cit. note 4, p. 45; Redfern et. al. o; cit. note 12, p. 332; Jens, op. cit. note 23, p. 440; Böckstiegel et al. op. cit. note 25, p. 783; Smahi, op. cit. note 29, pp 82; Alessi, op. cit. note 42, p. 738, 739; Onyema, E., International Commercial Arbitration and the Arbitrator's Contract, Routledge Research in International Commercial law, Abingdon, 2010, pp. 35, 165; Karrer, P. A., Responsibility of Arbitrators and Arbitral Institutions in: The Leading Arbitrators' Guide to International Arbitration, Third edition, Juris Publishing, Inc., New York, 2014, pp. 168

56 Hausmaninger, op. cit. note 4, p. 43, 44

57 Franck, op. cit. note 1, p. 49; Warwas, op. cit. note 6, p. 200

58 The London Court of International Arbitration Arbitration rules article 31.1

59 World Intellectual Property Organisation Arbitration rules, article 77

60 Hong Kong International Arbitration Center Arbitration rules, article 46.1

61 American arbitration association, Arbitration rules article 35

62 For acts in connection with deciding a legal matter, arbitrators are only liable for intentional breaches, Deutsche Institution für Schiedsgerichtsbarkeit, section 44

63 Arbitration Institute of the Stockholm Chamber of Commerce (2017), article 52

64 Article 45 of the Arbitration rules

65 Nederlands Arbitrage Instituut, 2015 Arbitration rules article 61 
ICC (2017), ${ }^{66}$ LAC (2014), ${ }^{67}$ VIAC (2018), ${ }^{68} \mathrm{FAI}(2017),{ }^{69} \operatorname{ICSID}(2006),{ }^{70}$ and AAA $(2004))^{71}$ with no exception for intentional breaches. ${ }^{72}$

Are these clauses valid?

The answer depends on the applicable national law. It is unlikely that arbitration rules could confer judicial immunity to arbitrators. In the Delubac case for example the Paris court of appeal held that these provisions only apply to the immunity arbitrators enjoy in the performance of their judicial function. The ICC could be liable for failing to comply with its essential obligation regardless of any liability exclusion clause (SNF v. Citec). ${ }^{73}$ Furthermore, no legal system allows unrestricted exclusion clauses. Civil law countries prohibit exonerations for gross negligence and intent in advance (France, Switzerland, Austria). Common law countries limit the effectiveness of exclusion clauses where they are held to be unconscionable (in the US) or when the arbitrator acted in bad faith. In most jurisdictions, the courts will be unwilling to enforce an exclusion clause that has not been negotiated by the parties but imposed as part of the general terms and conditions. ${ }^{74}$

Under Slovenian, German, Austrian and Swiss law absolute exclusion clauses would be considered void. According to the Austrian jurisprudence, liability for intent cannot be excluded in advance, whereas an exclusion of liability for gross negligence would be contrary to public policy under certain circumstances. ${ }^{75} \mathrm{Sim}$ ilarly, under Swiss law exclusion clauses are void unless they comply with article 100(1) Swiss Code of Obligations according to which liability for unlawful intent or gross negligence cannot be excluded in advance. This is reflected in the SCAI Arbitration rules (2017). ${ }^{76}$ German law also prevents exclusions of liability for deliberate wrongdoing. ${ }^{77}$ If the courts considered arbitration rules (or parts of it) as the general terms and conditions, clauses that exclude liability of the institution

\footnotetext{
66 International Chamber of Commerce Arbitration rules, article 41

67 Ljubljana Arbitration Centre, Arbitration rules article 52

68 Vienna International Arbitral Centre Arbitration rules 2018, article 46

69 Finland Arbitration Institute Arbitration rules 2017, article 51

70 Article 21 International Centre for Settlement of Investment Disputes (ICSID) Convention

71 Article 38 of the American Arbitration Association arbitration rules: International dispute resolution procedures 2014

72 Most arbitration rules (except WIPO, HKIAC, ICSID) add an exception "to the extent such limitation of liability is prohibited by applicable law"

73 Le club de juristes, op. cit. note 5, p. 34-36; Warwas, op. cit. note 6, p. 249-255; Redfern et. al. op. cit. note 12, p. 326; Alessi, op. cit. note 42, p. 736

$74 \quad$ Fouchard et. al, op. cit. note 1, p. 623

75 Austrian Arbitration Yearbook, str. 121, article 879 ABGB

76 Swiss chamber's arbitration institution Arbitration rules, article 45; Smahi, op. cit. note 4, p. 890

77 Article 276 (3) of the German Civil Code - Bürgerliches Gesetzbuch (BGB)
} 
(as it is the drafter of its rules) for gross negligence could be nullified as well (article 309 (7) of the German Civil Code). This would also apply to arbitrators when they were so closely connected to the institution that they could be considered as drafters and users of its rules. Even though this provision applies directly only to consumers it could be extended to businessman on a case to case basis. The nullity of a general term would lead to liability under general rules. ${ }^{78}$ Slovenian rules also prohibit contractual exclusions of liability for intent and gross negligence which would be null. ${ }^{79}$ There is no certainty that the courts would consider that the exclusion of liability for simple negligence (which could otherwise be agreed upon) would survive this invalidity. It seems unlikely that courts would be willing to reduce null exclusion clauses to an admissible level or apply any gap filling mechanism unless the validity of the arbitrator's contract depended on it, especially if it had been imposed upon, rather than negotiated by the parties to the arbitration..$^{80}$

\section{CONCLUSION - HOW WOULD A SLOVENIAN COURT DECIDE IN A LIABILITY CLAIM?}

In general, arbitrators are not liable for any errors in judgement they may commit. They enjoy a certain immunity regarding their judicial acts that protects them from liability claims based on accusations they have reached the wrong decision. However, they could be liable for breaches of their fundamental judicial duties: for non-performance and bad faith. In some civil law countries, they could also face liability for gross negligence and for breaches of their contractual duties (confidentiality).

Arbitrators should be required to compensate the parties for damages caused by serious breaches of their fundamental judicial duties. However, they must also enjoy a certain degree of immunity within their judicial role to ensure their independence, impartiality and the finality of their awards. The threat of liability claims against the arbitrator could challenge these principles. A qualified immunity where arbitrators were only liable in exceptional cases is the appropriate approach and provides a balance between the right to compensation and independence of arbitrators. In their judicial role arbitrators should enjoy immunity, excluded only in cases of fraud and intentional and serious violations of their judicial duties. This immunity regarding simple negligence should be a mandatory minimum standard

78 Jens, op. cit. note 23, p. 437, 438; Böckstiegel et al. op. cit. note 25, p., 783, 784

79 Obligacijski zakonik (Uradni list RS, št. 97/07 - uradno prečiščeno besedilo, 64/16 - odl. US, 20/18) article 242 and 86(1); Plavšak N et. al, Obligacijski zakonik (OZ) s komentarjem (splošni del), Volume 2, GV Založba, 2003 pp. 220

80 Fouchard et. al, op. cit. note 1, p. 623; Jens, op. cit. note 23, p. 437, 438; Böckstiegel et al. op. cit. note 25, p., 783,784 
of immunity for reasons of public policy (i. e. the independence of arbitrators). In other cases (not related to deciding the dispute), arbitrators should be liable according to the general rules of contract law. They should act with due diligence or they could be liable for negligence in the performance of their contractual obligations.

There is no legislation nor case law regarding the liability of arbitrators in Slovenia. ${ }^{81}$ This could lead to the application of ordinary contract law where the courts would determine the scope of liability depending on the qualification of the breached obligation (whether it is as an obligation of result or an obligation of means, article 619 or 766 of the Slovenian Civil Code).

Considering the similarities and connection of our civil law to the German and Austrian legal system, their solutions could serve as an example in developing our jurisprudence. In Germany arbitrators enjoy immunity (on a contractual basis) for actions within their judicial role ("bei dem Urteil"), except when the acts are intentional. In Austria arbitrators can only be liable if the award was set aside and there is proof of gross negligence on the part of the arbitrator. Which of these solutions should be adopted by Slovenian courts? The contractual basis for arbitral immunity in Germany has faced criticism since it allows parties to expressly agree to unlimited liability. The Austrian approach would therefore seem more appropriate although it can allow arbitrators to avoid liability when the injured party misses the short deadline for setting aside the award. Both countries extend a similar protection enjoyed by their national judges to arbitrators when they are exercising their judicial functions.

The regime regarding civil liability for judicial errors could therefore provide guidance in Slovenia, even if it cannot be applied to the arbitrator directly. The Slovenian courts could extend this approach to arbitrators by analogy that should be based on reasons of public policy (instead of a contractual basis) to ensure a minimum standard of protection to arbitrators that could not be derogated by contract. Judges in Slovenia enjoy material immunity for their opinions when deciding in court (article 134 of the Constitution) and cannot be sued directly (II Ips 111/2009). Only the state is liable for qualified errors: in cases of manifest and gross violations of the law and/or the judge's judicial duties that amount arbitrariness (for examples see II Ips 305/2017, II Ips 220/2017, II Ips 49/2017, II Ips

81 No national case law handling the question of their liability is to be found on the website: https://www. iusinfo.si and www.sodnapraksa.si. The literature is also scarce. To the author's knowledge only one paper briefly deals with this subject matter: Mežnar Š., Odgovornost pravnih poklicev - teorija in praksa, Pravni letopis, 2008, pp. 138, 143. The author concludes that arbitrators' liability should be treated akin to the judges' - they should be liable only in exceptional cases 
$252 / 2013$, etc.). It is unclear whether the state has a right of recourse when judges acted intentionally or grossly negligent (article 148 (2) of the Civil Code). Even though it seems unlikely that the courts could extend the constitutional immunity and the protection of exclusive state responsibility to arbitrators, they should benefit from the stricter standard of unlawfulness. This would exclude arbitrators' liability for errors made in reaching their arbitral award - they would not be liable for the procedural and material accuracy of their decision. The fact that the arbitral award was set aside, or its enforcement was refused would not render them liable automatically. They could be held liable only in situations when the state is liable for judicial misconduct, such as not applying a clear provision of substantive law or its erroneous interpretation that is incompatible with established case law without motivation (due to bias), gross violations of procedural rules - breach of the right to be heard. If the plaintiff failed to exhaust all legal remedies that could prevent the damage, the arbitrator would not be liable (for examples regarding state liability see III Ips 80/2017-3, II Ips 1014/2007, II Ips 275/2016, etc.). This liability regime would protect diligent arbitrators while at the same time discourage careless behaviour. In other situations (in his role as a contractual party), the arbitrator could be liable for simple negligence - for not performing his contractual duties with due care and skill: for not fulfilling his obligations (and failing to render an arbitral award) at all or in a timely manner, for issuing the award in the wrong place if it could not be enforced in the country of the losing party, for breach of confidentiality, for non-disclosing facts that could influence his independence. This approach would lead to the proposed scope of arbitral liability. It is worth mentioning that if arbitrators in Slovenia were found liable for negligence, it is questionable whether such a judgement could be enforced in countries where arbitrators enjoy broader immunity as part of mandatory law (for example article 29 of the English Arbitration Act 1996).

\section{REFERENCES}

\section{BOOKS AND ARTICLES}

1. Fouchard, P.; Gaillard E.; Goldman B., Fouchard, Gaillard, Goldman on international commercial arbitration, Kluwer Law International, The Hague, 1999

2. Franck, S., The Liability of International Arbitrators: A Comparative Analysis and Proposal for Qualified Immunity, New York Law School Journal of International \& Comparative Law, Vol. 20, Issue 1, 2000, pp. $1-60$

3. Holtzmann H; Neuhaus, J., A Guide to the UNCITRAL Model Law on International Commercial Arbitration: Legislative History and Commentary, Kluwer Law International, The Netherlands, 2015

4. Born, G., International Commercial Arbitration (Second Edition), Kluwer Law International, 2014, pp. 1962 - 2050 
5. Smahi, N., The Arbitrator's Liability and Immunity Under Swiss Law - Part I, ASA Bulletin, Kluwer Law International, Vol. 34 Issue 4, 2016, pp. 876 - 896

6. Pörnbacher, K.; Knief I., Liability of Arbitrators - Judicial Immunity versus Contractual Liability: Party Autonomy versus Autonomy of Arbitrators, Czech and Central European Yearbook of Arbitration, Juris, Huntington, 2012, pp. $211-227$

7. Mullerat R.; Blanch J., The Liability of Arbitrators: A Survey of Current Practice, Dispute Resolution International, Vol. 1., Issue 1, International Bar Association, 2007, pp. 99-123

8. Lew, J.; Mistelis, L.; Kroll, S., Comparative International Commercial arbitration, Kluwer Law International, The Hague, 2003

9. Hausmaninger, C., Civil Liability of Arbitrators - Comparative Analysis and Proposals for Reform, Journal of International Arbitration, Vol. 4, Issue 4, 1990, pp. 7-48

10. Le club de jurists: Ad hoc commitee, Report: The arbitrator's liability, Paris, 2017

11. Brown, J., The Expansion of Arbitral Immunity Is Absolute Immunity a Foregone Conclusion, Journal of Dispute Resolution, Vol. 2009, Issue 1, 2009, pp. 225-238

12. Warwas, B., The Liability of Arbitral Institutions: Legitimacy Challenges and Functional Responses, T.M.C. Asser press, The Netherlands, 2017

13. Born, G., International Arbitration: Law and Practice (Second Edition), Kluwer Law International, 2016, pp. 129-154

14. Hwang M., Chung K., Cheng F., Claims Against Arbitrators for Breach of Ethical Duties in Contemporary Issues in International Arbitration and Mediation, The Fordham Papers, New York, 2007, pp. 225-246

15. Truli E., Lability v. quasi-judicial immunity of the arbitrator: the case against absolute arbitral immunity, The American review of international arbitration, Vol. 7, 2006, pp. 1-31

16. Clay, T., L'arbitre, Dalloz, Paris, 2001

17. Redfern, A.; Hunter, M.; Blackaby N., Partasides C., Redfern and Hunter on International Arbitration, Sixth edition, Oxford University Press, New York, 2014

18. Viscasillas P., Civil Liability of Arbitrators and Arbitral Institutions in International Commercial Arbitration: The Development of the Arbitration Laws and Rules in the Last 30 Years, World Arbitration and Mediation Review, Vol. 7, Issue 2, 2013, pp. 405 - 420

19. Schwarz, F.; Konrad C., The New Vienna Rules, Arbitration International, Vol. 23, Issue 4, 2007, pp. 601-644

20. Ramadurai R., Arbitration in Dubai; Immunity of Arbitration Tribunals, Recent Judicial Verdicts, International Conference on Challenges in Domestic and International Arbitration, Chennai, 2016, pp. 31-37

21. Maisner M., Liability and Independence of the arbitrator, Czech and Central European Yearbook of Arbitration, Juris, Huntington, 2012 pp. 149 -167

22. Jens, G., Die Haftung des Schiedsrichters in der internationalen Handelsschiedsgerichtsbarkeit, Mohr Siebeck, Tübingen, 2009

23. K. Böckstiegel; S. M. Kröll; P. Nacimiento, Arbitration in Germany: the model law in practice, Second Edition, Wolters Kluwer Law \& Business, Alphen aan den Rijn, 2014 
24. Lagarde M., Liability of Arbitrators in Dubai: Still a Safe Seat of Arbitration, ASA Bulletin, Kluwer Law International 2015, Vol. 33, Issue 4, pp. 780-807

25. Smahi, N., The Arbitrator's Liability and Immunity Under Swiss Law - Part II, ASA Bulletin, Kluwer Law International, Vol. 35, Issue 1, 2017, pp. 67-83

26. Sutton D.; Gill J., Gearing, M., Russell on arbitration, Sweet \& Maxwell, London, 2007

27. Alessi, D. Enforcing Arbitrator's Obligations: Rethinking International Commercial Arbitrators' Liability, Journal of International Arbitration, Vol. 31, Issue 6, 2014, pp. 735-784

28. Giraud, P., Le devoir de l'arbitre de se conformer à sa mission, Bruylant, Bruxelles, 2017

29. Sammartano M. R., International arbitration law and practice, JurisNet, Huntington, 2014

30. Onyema, E., International Commercial Arbitration and the Arbitrator's Contract, Routledge Research in International Commercial law, Abingdon, 2010

31. Karrer, P. A., Responsibility of Arbitrators and Arbitral Institutions in: The Leading Arbitrators Guide to International Arbitration, Third edition, Juris Publishing, Inc., New York, 2014, pp. 161-174

32. Plavšak N. et. al, Obligacijski zakonik (OZ) s komentarjem (splošni del), Vol. 2, GV Založba, Ljubljana, 2003

33. Mežnar Š., Odgovornost pravnih poklicev - teorija in praksa, Pravni letopis, Inštitut za primerjalno pravo, Ljubljana, 2008, pp. 133-143

\section{COURT OF JUSTICE OF THE EUROPEAN UNION}

1. Case C-224/01 Köbler v Austria (2003)

2. Case C-173/03 Traghetti del Mediterraneo SpA v Repubblica italiana (2006) par. 46

\section{WEBSITE REFERENCES}

1. Grill, A; Lukic S., Arbitrators' Liability: Austrian Supreme Court Reconfirms Strict Standards, Kluwer Arbitration Blog, 2016. [http://arbitrationblog.kluwerarbitration.com/2016/09/01/ arbitrators-liability-austrian-supreme-court-reconfirms-strict-standards/] Accessed 27.02.2019

2. Dittrich, L.; Curatola M., Luca F., Commercial Arbitration: Italy, 2017. [https://globalarbitrationreview.com/jurisdiction/1002557/Italy] Accessed 07.03.2019 